\title{
PRELIMINARY INVESTIGATIONS ON INTRODUCTIONS OF SPECIES OF THE GENUS POA L. IN NEW ZEALAND
}

\author{
J. B. FergusSON
}

Grasslands, Division, DSIR, Palmerston N orth

\begin{abstract}
Forty-five lines of 11 species of Poa were introduced and grown as spaced plants in winter and spring plantings at four locations. Visual assessment was made of growth habit, relative vigour and incidence of disease. Establishment of $\mathbf{P}$. trivialis, $P$. palustris and $P$. nemoralis was good, but subsequently all Poa lines were markedly inferior to the controls, being either small or prostrate or very erect and stemmy. Many lines were very susceptible to Puccinia poae-nemoralis Otth., a rust which is frequent among local populations of $P$. pratensis. It was concluded that introduced Poa species arc unlikely to be of agricultural importance in New Zealand although P. pratensis may be valuable in areas of dry summers and cold winters such as the Mackenzie Country. It is suggested that further trials be carried out in this area including local ecotypes of $P$. pratensis.
\end{abstract}

\section{INTRODUCTION}

The genus Poa is a highly successful group of mostly temperate grasses adapted to a wide range of environments. The greatest differentiation in the genus occurs at high latitudes and altitudes, and species occurring in the tropics are only found in mountainous areas, especially the Andes. It 'has been shown that the governing factor is summer temperature, and. the genus thrives where this is not high (Hartley, 1961).

However, many species are adapted to milder conditions, and these have been important pasture plants for hundreds of years. The most valuable species in current agricultural use is Poa pratensis L., which is used extensively in Europe and the U.S.A., and is the major pasture species in Sweden (Almgard, 1966). Other species, notably P. palustris L., P. nemoralis L. and P. trivialis L. are all used commercially overseas, and have been improved to the extent that registered cultivars exist. There are also many "dryland" species which are used in the prairies of the U.S.A. and Canada, and some have been developed for special purposes such as erosion control. 
The genus is well represented in New Zealand, but the introduced species are generally considered to be pasture weeds (e.g., P. annua L. and P. trivialis (Sears, 1960)). Although P. pratensis is important overseas, the best pastures produce only approximately one-sixth the yield of a good New Zealand ryegrass sward (Levy, 1955). However, there are areas in the South Island of New Zealand with a climate to which these species are adapted, and it was considered desirable to introduce and test overseas lines in an effort to determine whether there may be potential in the genus for some areas.

\section{EXPERIMENTAL}

Forty-five lines of Poa were introduced comprising 11 species (Table 1). These were planted in two separate experiments, using perennial ryegrass, timothy and Phalaris cultivars as controls.

TABLE I: SPECIES, CULTIVAR AND ORJGIN OF INTRODUCED LINES AND CONTROLS

\begin{tabular}{|c|c|c|c|}
\hline \multicolumn{4}{|c|}{ Line } \\
\hline 1 & l. nemoralis & Brabantia & Netherlands \\
\hline 2 & P. pratensis & Collection & Netherlands \\
\hline 3 & P. pratensis & Collection & Gard, France \\
\hline 4 & P. pratensis & Collection & Centrale, France \\
\hline 5 & $P$. prafensis & Collection & Hungary \\
\hline 6 & P. pratensis & Collection & Loiret, France \\
\hline 7 & P. subcaerulea & Collection & Finistère, France \\
\hline 8 & P. angustifolia & Collection & Pay de Dome, France \\
\hline 9 & $P$. lanuginosa & Collection & Argentina \\
\hline 10 & $\mathrm{P}$, palustris & Collection & Nitvre, France \\
\hline 11 & P. compressa & Collection & Loiret, France \\
\hline 12 & P. ampla & Collection & Argentina \\
\hline 13 & P. ampla & Sherman & France \\
\hline 14 & P. pratensis & Aboretum & U.S.A. \\
\hline 15 & P. prafensis & Merion & U.S.A. \\
\hline 16 & P. pratensis & Newport & U.S.A. \\
\hline 17 & P. pratensis & Nudworf & U.S.A. \\
\hline 18 & P. pratensis & Nugget & U.S.A. \\
\hline 19 & P. prafensis & Park & U.S.A. \\
\hline 20 & $P$. pratensis & Campus & U.S.A. \\
\hline 21 & P. pratensis & Cougar & U.S.A. \\
\hline 22 & P. pratensis & Delta & U.S.A. \\
\hline 23 & P. prafensis & Kenblue & U.S.A. \\
\hline 24 & P. prafensis & Troy & U.S.A. \\
\hline 25 & P. ampla & Sherman & U.S.A. \\
\hline
\end{tabular}


TABLE 1: contd.

\begin{tabular}{|c|c|c|c|}
\hline No. & Species & Cultivar & Origin \\
\hline 26 & P. glaucantha & Draylar & U.S.A. \\
\hline 27 & P. pratensis & Norma Otofte & Denmark \\
\hline 28 & P. prafensis & Otofte & Denmark \\
\hline 29 & P. trivialis & Omega Otofte & Denmark \\
\hline 30 & P. pratensis & Arista & Netherlands \\
\hline 31 & Lolium perenne & Grasslands Ruanui & 7 \\
\hline 32 & Lolium $\times$ hybridum & Grasslands Ariki & \\
\hline 33 & Lolium perenne & Grasslands 4711 & \\
\hline 34 & Lolium perenne & Medea & \\
\hline 35 & Dactylis glomerata & Grasslands Apanui & Controls \\
\hline 36 & Dactylis glomerata & Selection & \\
\hline 37 & Agrostis fenuis & N.Z. Certified & \\
\hline 38 & Phalaris tuberosa & Seedmaster & $10 \cos (x)$ \\
\hline 39 & P. pratensis & Skandia II & Sweden \\
\hline 40 & P. pratensis & Fylking & Sweden \\
\hline 41 & P. pratensis & Atlas & Sweden \\
\hline 42 & P. pratensis & Barkenta & Netherlands \\
\hline 43 & P. pratensis & Baron & Netherlands \\
\hline 44 & P. pratensis & Captan & Netherlands \\
\hline 45 & P. pratensis & Olympic & Germany \\
\hline 46 & P. angusitifolia & Collection & France \\
\hline 47 & P. interior & Collection & Canada \\
\hline 48 & P. pratensis & S.K. 46 & Poland \\
\hline 49 & P. nemoralis & Collection & France \\
\hline 50 & $P$. nemoralis & Barnemo & Netherlands \\
\hline 51 & P. palustris & S.K. 47 & Poland \\
\hline 52 & P. palustris & Wepal & Germany \\
\hline 53 & P. trivialis & Collection & France \\
\hline
\end{tabular}

EXPERIMENT 1

Lines 1 to 38 were grown in glasshouses and transferred to peat "Jiffy" pots in which they were later planted out in winter 1970 at $6 \mathrm{~cm} \times 30 \mathrm{~cm}$ spacing directly into holes cut by a corer in a sward which had been killed with paraquat. Three sites were chosen: Porangahau, on the East Corast, in an area of mild winters and hot dry summers; Ballantrae in the scuthern Ruahines, in a region of high rainfall and cold winters; and at Aorengi on the Manawatu plain.

A randomized block design, with six replicates of five plants, was used.

Since direct planting into chemically killed swards had not been used previously, a control planting at $60 \mathrm{~cm} \mathrm{x} 60 \mathrm{~cm}$ spacings in cultivated ground was made. 
Lines 31 to 53 were grown in the glasshouse and planted directly into cultivated ground at Palmerston North on October 30,1970 , using the $60 \mathrm{~cm} \times 60 \mathrm{~cm}$ arrangement.

Growth was coatrolled in both experiments by periodic mobgrazing with sheep, although, since growth habit of species was under investigation, plants were allowed to flower at Aorangi and Palmerston North.

Weed control was necessary, and all areas except Porangahau received 3.4 litres/hectare "Dicambone" (5\% a.i. dicamba) in spring. Weed control in the "cultivated" blocks was by rotary hoeing.

Relative growth was recorded by visual assessment, before grazing, using a 0 to 5 scale, depending upon the relative size and vigour of the plants. A vigorous plant was considered to be one showing strong, leafy growth with little dead or decaying matter and relatively free of disease.

RESULTS

EXPERIMENT 1

The use of peat pots for establishment in the chemically treated swards proved successful and the majority of plants established well. At Aocangi, although the uncultivated plots appeared to be slightly less vigorous than the cultivated ones, no significant differences in vigour were detected between the two types of planting. There was a great variation of growth form both within land between introduced 'species, ranging from small, prostrate and leafy types, to stemmy and very erect types. Very few lines were leafy and relatively high-yielding. Poa pratensis lines established slowly, and the results for the cultivar 'Newport' (Table 2) are typical. Line 3, a collection from Gard, France, was generally the best of this species, persisting well at Porangahau under strong competition from weeds. However, it is moderately susceptible to rust and certainly did not compare with the better control lines in vigour. Poa trivialis, P. nemoralis and $P$. palustris were promising for the first few months but were considerably inferior to the controls by midsummer. Poa ampla Merr., an erect species, was also vigorous early in the experiment, but became very stemmy at flowering and succumbed to a heavy infection of rust. Of the other lines, none was outstanding, and some died within six months of planting. 
TABLE 2: RELATIVE GROWTH OF TEN CULTIVARS BY VISUAL ASSESSMENT

(Expressed as a percentage of 'Grasslands 4711' Lolium percnne)

\begin{tabular}{|c|c|c|c|c|}
\hline \multirow[b]{2}{*}{ Species/Cultivar } & \multirow{2}{*}{$\begin{array}{c}\text { Pre- } \\
\text { planting }\end{array}$} & \multicolumn{2}{|c|}{ A orangi } & \multirow{2}{*}{$\begin{array}{l}\text { Balantrae } \\
\text { Summer }\end{array}$} \\
\hline & & Spring & Summer & \\
\hline 1 P. nernoralis - 'Brabantia' & 107 & 68 & 48 & 56 \\
\hline 3 P. pratensis - France & 70 & 62 & 49 & 38 \\
\hline 10 P. palustris - France & 104 & 64 & 59 & 60 \\
\hline 12 P. ampla - Argentina & 93 & 85 & 56 & 33 \\
\hline 16 P. pratensis - 'Newport' & 59 & 53 & 25 & 26 \\
\hline 26 P. glaucantha - 'Draylar' & 67 & 37 & 10 & 20 \\
\hline 29 P. trivialis $=$ 'Omega Otofte' & 111 & $86 *$ & 56 & 54 \\
\hline 33 L. perenne - 'G4711' & 100 & 100 & 100 & 100 \\
\hline 37 A. tenuis - N.Z. Cert. & 67 & $68 *$ & 48 & 54 \\
\hline 38 Phalaris tuberosa $\rightarrow$ 'Seedmaster' & 89 & 93 & 90 & 70 \\
\hline Standard, error & \pm 4.4 & \pm 9.8 & \pm 6.6 & \pm 3.0 \\
\hline
\end{tabular}

*Cultivated plots only.

The effect of site on species performance was complicated by problems of rust 'and, more especially, weed control. Furthermcce, owing to the differing growth rates and differing climates associated with the three sites, it proved impossible to note plants at the same stage of growth, so any comparisons between sites are subjective. Generally, however, all plants grew best at Aorangi, and this was especially noticeable in the control plants which grew to many times the size of the same lines at Ballantrae. Even so, a comparison of vigour ratings on December 21 at Aorangi and December 22 at Bellantrae showed no significant 'differences in the ranking of species between sites.

Although mob stocking was used, preferential grazing of different lines depending on their stage of flowering was a problem which undoubtedly affected later results. In addition, at Ballantrae and Porangahau plots were occasionally left ungrazed for longer periods than was desirable, accentuating the problem of stemminess in early-flowering lines, weed invasion, and rust infectioa.

Rust (Puccinila spp.) was prevalent (throughout the trial, some species being severely attacked, although others we're unaffected. Poa ampla, P. nemoralis and P. pratensis cultivars 'Merion', 'Newport', 'Nugget' and 'Arista' were all heavily infected, and $P$. glaucantha was almost killed. However, other lines, notably P. trivialis, P. compressa L. and P. subcaerulea Sm. were only lightly attacked, and most of the control lines were completely unaffected until later in the trial. 


\section{EXPERIMENT 2}

The late spring planting was followed by a long dry summer, and this influenced results considerably. Plants which were small or slow to establish suffered severely from the desiccation of the topsoil, while deeper rooting species thrived.

Thus P. trivialis established well (Table 3), but by the end of summer had almost died out. On the other hand, Phalaris tuberosa was particularly vigorous throughout the assessment period and it was necessary to cut it twice during summer. Poa angustifolia L. was the most vigorous of the introductions, being strongly rhizomatous, and spreading very quickly. 'Sltandia II' was the best $P$. pratensis, while lines 1 and 10 appeared to suffer severely from the drought.

TABLE 3: RELATIVE GROWTH OF EIGHT CULTIVARS BY VISUAL ASSESSMENT

(Expressed as a percentage of 'Grasslands 4711' Lolium perenne)

\begin{tabular}{|c|c|c|c|c|}
\hline Species/Cultivar & $\begin{array}{c}\text { Pre- } \\
\text { planting }\end{array}$ & Autumn & Spring & Summer \\
\hline 39 :P. pratensis - 'Skandia II' & 48 & 50 & 38 & 44 \\
\hline $46 P$. angustifolia $=$ France & 37 & 55 & 53 & 52 \\
\hline 1 P. nemoralis - 'Brabantia' & 68 & 18 & 33 & 15 \\
\hline $10 P$. palustris - France & 78 & 30 & 29 & 13 \\
\hline 29 P. trivialis - 'Omega Otofte' & 88 & 1 & 10 & 7 \\
\hline 33 L. perenne - 'G4711' & 100 & 100 & 100 & 100 \\
\hline 37 A. tenuis - N.Z. Cert. & 75 & 62 & 67 & 86 \\
\hline 38 Phalaris tuberosa - 'Seedmaster' & 80 & 128 & 121 & 170 \\
\hline Standard error & - & \pm 3.4 & \pm 4.0 & \pm 4.5 \\
\hline
\end{tabular}

Rust affected most of the Poa species, especially P. pratensis. However, P. nemoralis cv. 'Barnemo', P. trivialis and P. angustifolia were almost completely unaffected. The pattern of infection in this trial closely resembled that in Experiment 1. Poa species became heavily infected early in spring, and the ryegrass in early summer. The early spring infection was confirmed as Puccinia poae-nemoralis Ot th. (J. M. D ingley, pers. comm.) and the later oae consisted mainly of P. coronata Corda. Phalaris tuberosa and Agrosfis tenuis were disease-free.

\section{DISCUSSION}

While the early establishment of plants into chemically treated swards indicated the method could be useful, the subsequent 
severe weed problems caused the experiment to end prematurely. The principal cause appeared to be the use of too low a rate of paraquat.

It is generally considered that one of the main drawbacks of Poa species is their slow establishment (Whyte et al., 1939). Early establishment was also slow in these experiments, compared with perennial ryegrass, with the possible exception' of $\mathrm{P}$. trivialis, P. nernoralis, P. palustris, and P. ampla. These species showed reasonable vigour when planted in cool winter conditions but they suffered badly from drought stress following the spring planting.

The fact that many lines were very small and slow establishing meant that they could not successfully compete with the volunteer grasses. Susceptibility to rust and poar control of grazing aggravated the problem. But despite the lack of data from this experiment the spring planting in Experiment 2, under fertile conditions, still demonstrated the relative lack. of vigour.

Poa ampla is reputedly a dryland species, but it is probably adapted to a climate of moist winters and dry summers. It demonstrated winter growth and summer dormancy in this trial, becoming tufted and coarse, and unpalatable to sheep (cf. Almgard, 1960). Poa angustifolia, on the other hand, remained green and disease-free throughout the summer, but was never as vigorous as the ryegrasses.

It is therefore considered that these Poa introductions are unlikely to be of much value where it is possible to grow ryegrass successfully. Where this is not the case - i.e., in dry areas and on infertile hill country - there may be better prospects for their use. However, it appears that the species supposedly well adapted to dry conditions - e.g., P. glaucantha, P. ampla, and $P$. compressa - are low yielding or unsuitable for reasons already mentioned. Nevertheless, there were a number of lines which were as vigorous as browntop. However, at Ballantrae the whole site was overrun by native browntop within nine months of planting, and only the ryegrass controls stood above the volunteer grass.

Both P. prafensis and P. trivialis commonly exist in New Zealand pastures (Levy, 1955; Round-Turner, 1970) and frequently contribute a significant proportion of the total dry matter (Maclean, 1958; Vartha, 1965; Palmer, 1970). Poa pratensis is widely distributed throughout the country, and is prevalent in areas of low rainfall and cold winters. It is one of the dominant species in much of Mackenzie Country (Fergusson, unpubl. data) and 
appears to be batter adapted to this climate than other introduced grasses. Obviously, therefore, these grasses have some potential in this environment. Both $\mathrm{P}$. pratensis and $\mathrm{P}$. trivialis have been in this country for at least 100 years (Thomson, 1922), and local strains will almost certainly exist. This has been confirmed by Vartha (1969) who collected seed of P. trivialis, and found considerable variation in form within a relatively small area of the country. Furthermore, a collection made by the writer showed wide variation in P. pratensis. Coastal strains from Otago Peninsula were small and low growing, while lines from Central Otago and South Canterbury were broad in the leaf with large, erect panicles. It is possible that some of these New Zealand ecotypes may show better winter growth than overseas lines which will enable them to compete better with the local vegetation, especially browntop.

Investigation showed that rust was prevalent among local populations of $P$. pratensis, and plants collected from other areas of the country also rapidly became infected when planted in the field. It is possible that the dry conditions to which this species is adapted normally prevent widespread infection, and that, when these plants are grown under the moister conditions of the lower half of the North Island, they become more susceptible to attack. Thus, while the rust is present in dry areas, the importance of disease and resistance among introductions may be reduced under conditions which are not conducive to rapid infection.

This preliminary investigation suggests that Poa species are of little value as pasture plants in regions such as the southern North Island because of their slow establishment and susceptibility to rust.

However, study of local populations of $P$. pratensis suggests that furbher work with the genus is warranted in dry areas which suffer from cold winters. Poa angustifolia, with its ability to spread quickly, may be a useful soil-binder, while the economic importance of local ecotypes need's to be properly assessed under these conditions.

\section{ACKNOWLEDGEMENTS}

The author is grateful to the late Dr P. C. Barclay for suggesting this investigation and wishes to thank A, B. Langley for very kindly allowing the use of his land at Porangahau, Dr G. C. M. Latch and Miss J. M. Dingley for identification of rust species, and J. A. Lancashire for valuable help with discussion. 


\section{REFERENCES}

Almgard, G., 1960: Proc. 8th int. Grassld Congr.: 71 1966: LantbHogsk Annlr., 32: 3.

Hartley, W., 1961: Aust. I. Rot., 9: 152.

Levy, E. B., 1955: Grasslands of N ew Zealand, 2nd ed. Govt. Printer, Wellington.

Maclean, S. M. 1958: Proc. N.Z. Grass/d Ass., 20: 127.

Palmer, P. C., 1970: Proc. N.Z. Weed \& Pest Control Cont., 23: 51.

Round-Turner, N. L., 1970: Proc. N.Z. Weed \& Pest Control Conf., 23: 57.

Sears, P. D., 1960: Proc. 8th int. Grassld Congr.: 130.

Thomson, G. M., 1922: The Naturalisation of A nimals and Plants in $\mathrm{N}$ ew Zealand. Cambridge University Press, London.

Vartha, E. W., 1965: Proc. N.Z. Grassld A ss., 27: 102.

1969: A spects of the Agronomy and Ecology of Poa trivialis in Pastures. Ph.D; thesis, Massey University.

Whyte, R. O.; More, T. R. G.; Cooper, T: P., 1959: Grasses in agriculture. FAO A gric. Studies N 0. 42. FAO, Rome. 